\title{
Solar Energy Potential in Kathmandu Valley, Nepal
}

\author{
Santosh $\operatorname{Regmi}^{1^{*}}$ and Sunil Adhikary ${ }^{2}$ \\ Nepal Hydrological and Meteorological Research Centre, Kathmandu, Nepal \\ Department of Meteorology, Tri-Chandra Multiple Campus, Tribhuvan University, Kathmandu
}

\begin{abstract}
Meteorological data such as solar radiation (1975-1984, and 2002-2010) and sunshine duration (1968-2004) were analyzed to study temporal characteristics of solar energy and investigate solar energy potential in Kathmandu valley. Pre-monsoon and post monsoon seasons have higher mean monthly sunshine duration (about 8 hours/day) than summer (about 5 hours/day) and winter (about 7 hours/day) seasons over Kathmandu. Pre-monsoon and monsoon seasons receive solar energy of about $190 \mathrm{Wm}^{-2}$ and $170 \mathrm{Wm}^{-2}$ respectively. The winter season receives the least amount of solar radiation (135 $\left.\mathrm{Wm}^{-2}\right)$. Approximately $220 \mathrm{MW}$ of solar electricity can be produced in Kathmandu that will substantially fulfill current energy demand and reduce environmental pollution in the valley by replacing fossil fuels with clean solar electricity.
\end{abstract}

Keywords: Renewable energy, Solar energy, Environmental pollution, Kathmandu

\section{INTRODUCTION}

Nepal, a Himalayan country, is facing acute energy crisis (NEA: www.nea.org.np). The present energy demand of Nepal have been fulfilled, partly from hydropower, Bio-gas, fossil fuels and traditional energy sources, such as fire wood, cow dung and coal (Bajgain and Shakya, 2005; NOC: www.nepaloil.com). The use of renewable energy is negligible. Renewable energy is the energy obtained from the continuing or repetitive currents of energy occurring in the natural environment. Obvious example of renewable energy is solar (sunshine) energy (Neville, 1995). Conventional energy sources such as fire-wood, cow dung, coal and fossil fuels (petroleum products) release more $\mathrm{CO}_{2}$ into the atmosphere, causing environmental pollution problems that are directly related to the survival of human beings (Adhikari, 2007). Environmental pollution problems include ex- cessive release of green house gases (mainly $\mathrm{CO}$, $\mathrm{CO}_{2}, \mathrm{CH}_{4}, \mathrm{~N}_{2} \mathrm{O}$ and HFCs) into the atmosphere. These gases are responsible for the environmental pollution and the terrestrial heat trapped by them adversely changing the earth's climate due to increasing regional or global air temperature (Oke, 1999). The prevailing problems have urged researchers to develop renewable and clean energy resources as alternatives to fossil fuels (Schweizer et al., 1995; Umeno, 2003). In other words, widespread use of renewable energy has been emerged as an alternative solution to the environmental pollution problems.

Power crisis (i.e. increasing demand and negligible availability of Energy) in Kathmandu valley has been miserable for years. The valley is also facing severe environmental pollution problems due to excessive use of fossil fuels (WECS, 2006; NOC: www.nepaloil.com). Development of renewable energy such as, solar energy and it's considerable use in the valley

${ }^{\star}$ Corresponding author: Santosh Regmi, Email: sregmi11@yahoo.com 
can significantly support energy demand and contribute to reduce air pollution problem in the valley (Pokharel, 1998). In order to explore the possibility and reliability of using solar energy, however, it is important to understand temporal characteristics of solar energy and investigate it's potential in the valley. The purpose of this paper is to report possible sunshine hours and temporal (diurnal and seasonal) variations of solar radiation, and estimate solar energy potential in Kathmandu valley. The importance and scope of solar energy in the valley is also discussed briefly.

\section{STUDY AREA}

Kathmandu valley, the capital city of Nepal is situated in the mid hilly region of Nepal, where a number of mountain ranges entered generally east-west parallel to the great Himalayas. Within the Kathmandu valley, there are four other smaller municipalities and about a hundred Village Development Committees (VDCs). Kathmandu valley, which provides the physical setting for Kathmandu Metropolitan City (KMC), is situated between the latitudes $27^{\circ} 32^{\prime} 13^{\prime \prime}$ and $27^{\circ} 49^{\prime} 10^{\prime \prime}$ north and longitudes $85^{\circ} 11^{\prime} 31^{\prime \prime}$ and $85^{\circ} 31^{\prime} 38^{\prime \prime}$ east. It covers an area of about 667 sq. $\mathrm{km}$ and its mean elevation is about $1350 \mathrm{~m}$, above sea level (a.s.1.). The highest hill surrounding the valley is Phulchoki (2785 $\mathrm{m}$ a.s.1.) in the southeast, Shivapuri (2713 $\mathrm{m}$ a.s.1.) in the north, Chandragiri (2250 $\mathrm{m}$ a.s.1.) in the southwest and Nagarjun (2100 m a.s.1.) in the western corner. Surrounding hills are covered with shrubs at higher altitudes and in some places slightly to moderately dense forests. The cross section of the Kathmandu Valley that is oval in shape is about $20 \mathrm{~km}$ from north to south and 30 $\mathrm{km}$ from east to west (Regmi, 2010).

Figure 1a shows the location of study area with the map of Nepal. Figure $1 \mathrm{~b}$ shows the detailed map of the study area, where three districts, namely Kathmandu, Bhaktapur and Lalitpur

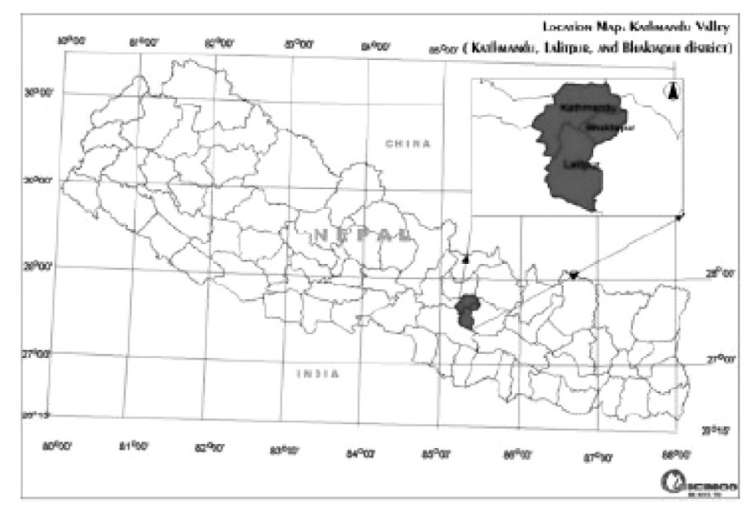

Figure 1a: Map of Nepal showing location of the study area within it.

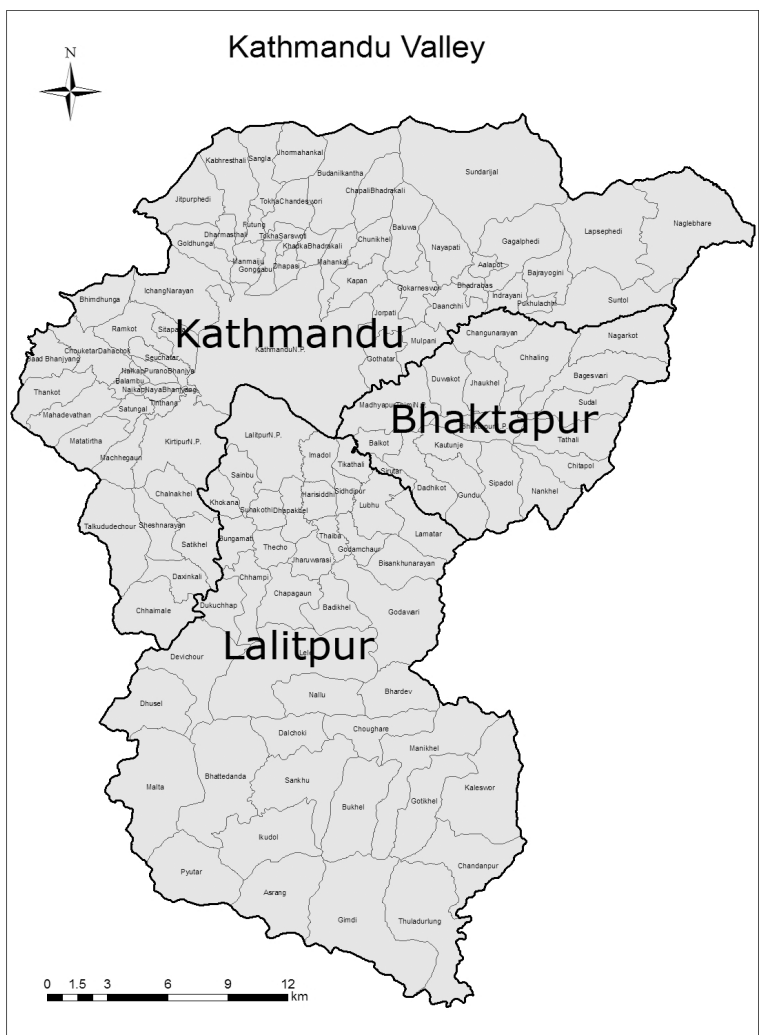

Figure 1b: Map of Kathmandu valley; within the valley Kathmandu, Bhaktapur and Lalitpur districts are located.

are located. On the map other features, such as VDCs, names of key locations and road networks are also seen. 


\section{DATA AND METHODOLOGY}

Meteorological data such as solar radiation (1975-1984, and 2002-2010) and sunshine duration (1968-2004) were collected from the Department of Hydrology and Meteorology (DHM), Ministry of Environment, Science and Technology, Government of Nepal. Monthly mean values for solar radiation and sunshine duration were derived from daily mean (12hour mean) values. Information and data related to energy, fuels and households were obtained from reports and homepages of Water and Energy Commission Secretariat (WECS), Nepal Oil Corporation (NOC) and Central Bureau of Statistics (CBS).

Solar energy potential (SEP) in Kathmandu was calculated based on annual mean solar radiation $(\mathrm{Sn})\left(\mathrm{Wm}^{-2}\right)$, solar panel efficiency $(\eta)$ $(20 \%)$ available in the market, $20 \%$ roof area of a house (Ar) that can be used for solar panel (200 sq. ft. or, $18.58 \mathrm{~m}^{2}$ ) and total households in Kathmandu valley (Nh) (according to 2011 CBS report, total number of households in Kathmandu valley is 3,66,003).

Hence, SEP can be calculated as,

$\mathrm{SEP}=\mathrm{Sn} \times \eta \times \mathrm{Ar} \times \mathrm{Nh}$

Various materials and data from the secondary sources, such as CBS-number of household in Kathmandu valley, average roof area of a house (1,000 sq.ft.), and availability of solar panels in the market were collected. The sunshine, solar radiation and solar energy potential data are presented in simple graphical plots (i.e. line and bar graphs) and a Table.

\section{RESULTS AND DISCUSSION}

Figure 2 shows diurnal variations of solar radiation in different seasons in Kathmandu valley, based on hourly data on 2010 . The maximum

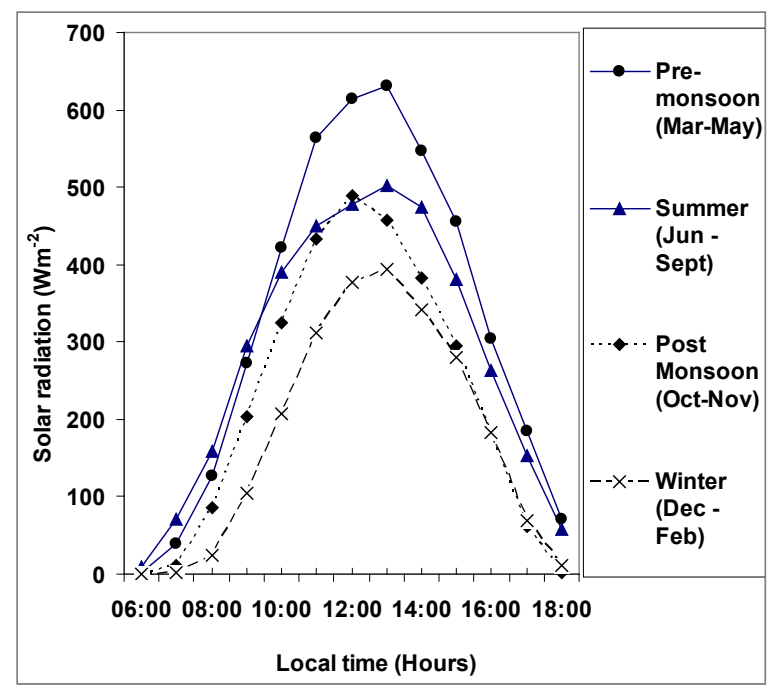

Figure 2: Diurnal variations of solar radiation in Kathmandu Valley.

solar radiations (i.e. peak values) $631.5 \mathrm{Wm}^{-2}$, 502.7 $\mathrm{Wm}^{-2}, 489.4 \mathrm{Wm}^{-2}$ and $394.5 \mathrm{Wm}^{-2}$ are found generally at noon time for pre-monsoon, summer, post-monsoon and winter seasons respectively.

Table 1: Solar energy and solar energy potential for Kathmandu valley.

\begin{tabular}{|c|c|c|c|}
\hline Months & $\begin{array}{c}\text { Sunshine } \\
\text { duration } \\
\text { (Hours) }\end{array}$ & $\begin{array}{c}\text { Mean } \\
\text { monthly solar } \\
\text { radiation } \\
\left(\mathrm{Wm}^{-2}\right)\end{array}$ & $\begin{array}{c}\text { Solar } \\
\text { energy } \\
\text { potential } \\
(\mathrm{MW})\end{array}$ \\
\hline Jan & 6.5 & 131 & 178 \\
Feb & 7.4 & 152 & 207 \\
Mar & 7.8 & 174 & 237 \\
Apr & 7.8 & 190 & 258 \\
May & 7.7 & 195 & 265 \\
Jun & 5.6 & 178 & 243 \\
Jul & 4.0 & 167 & 227 \\
Aug & 4.9 & 163 & 222 \\
Sep & 5.1 & 157 & 213 \\
Oct & 7.4 & 172 & 234 \\
Nov & 7.4 & 143 & 195 \\
Dec & 6.6 & 123 & 168 \\
\hline Average & 6.5 & 162 & 220 \\
\hline
\end{tabular}

Figure 3 and Table 1 show the mean monthly sunshine duration over Kathmandu valley. It is clear that pre-monsoon (Mar-May) and post 
monsoon (Oct-Nov) seasons have higher sunshine duration (about 8 hours/day) than summer (Jun-Sept) (about 5 hours/day) and winter

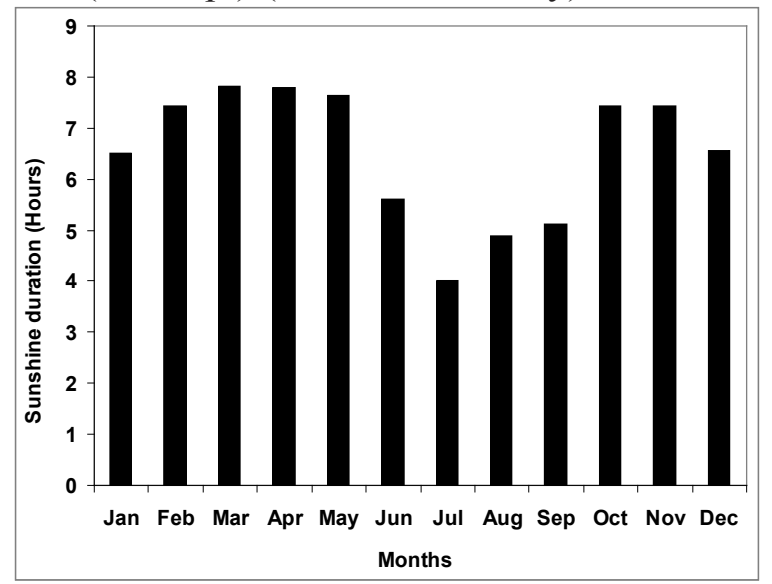

Figure 3: Mean monthly sunshine duration over Kathmandu Valley

(Dec-Feb) (about 7 hours/day) seasons. The lowest sunshine duration during summer season is attributed to the effect of clouds during that period (Nayava, 1979; Ibrahim, 1985; Oke, 1999; Adhikari et al, 2003). In an earlier study, Nayava (1979) reported more than $70 \%$ of possible sunshine occurrence during the post-monsoon and winter periods when there are almost no clouds in Kathmandu. However, present study shows that $53 \%$ of possible sunshine occurs during the post-monsoon and winter periods. The significant decrease of sunshine duration over the last three decades is probably due to high levels of scattering and reflection by dust and carbon soot produced from increasing number of infrastructures and vehicles and climate change (Paudel, 2011; Nayava, 2012).

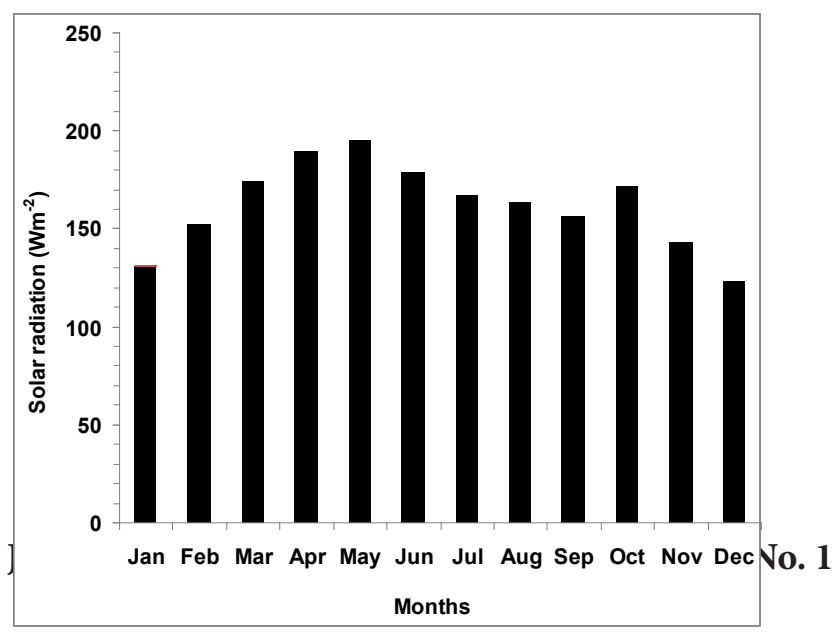

Figure 4: Mean monthly solar radiation of Kathmandu valley.

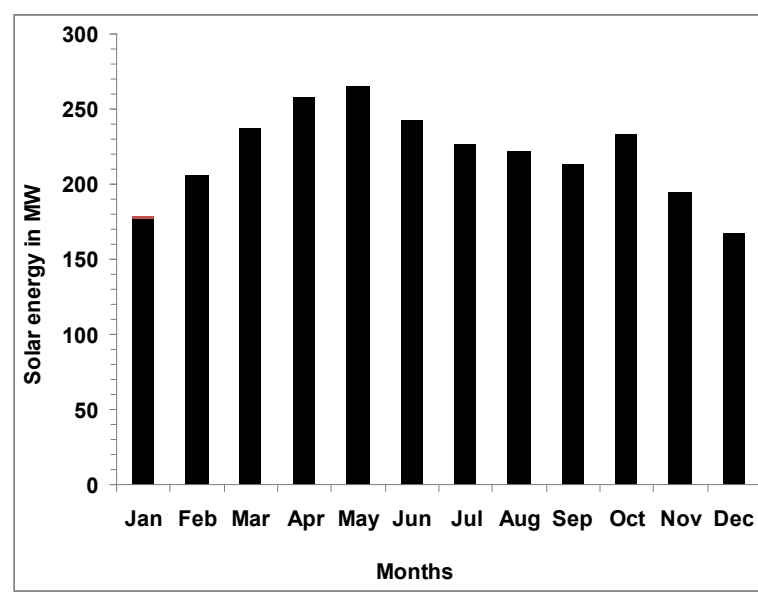

Figure 5: Solar energy potential in Kathmandu valley.

Figure 4 and Table 1 show mean monthly solar radiation intensity in Kathmandu valley. Premonsoon and monsoon seasons receive solar energy of about $190 \mathrm{Wm}^{-2}$ and $170 \mathrm{Wm}^{-2}$ respectively. The winter season receives the least amount of solar radiation $\left(135 \mathrm{Wm}^{-2}\right)$.

Figure 5 shows solar energy potential is slightly higher during pre-monsoon season compared to the monsoon season. Approximately $220 \mathrm{MW}$ of solar electricity can be produced in Kathmandu (Table 1) that will substantially fulfill current energy demand and reduce environmental pollution by replacing fossil fuels with clean solar electricity.

\section{CONCLUSIONS AND RECOMMENDATION}

In this study, meteorological data such as solar radiation and sunshine duration were analyzed to understand temporal characteristics of solar energy and investigate solar energy potential in Kathmandu valley. The results suggest high prospect of solar energy (clean energy) potential in Kathmandu valley.

The following conclusions are obtained from the present study.

1. Pre-monsoon and post monsoon seasons have higher mean monthly sunshine du- 
ration (about 8 hours/day) than summer (about 5 hours/day) and winter (about 7 hours/day) seasons over Kathmandu.

2. Pre-monsoon and monsoon seasons receive solar energy of about $190 \mathrm{Wm}^{-2}$ and $170 \mathrm{Wm}^{-2}$ respectively. The winter season receives the least amount of solar radiation $\left(135 \mathrm{Wm}^{-2}\right)$.

3. Approximately $220 \mathrm{MW}$ of solar electricity can be produced in Kathmandu that will substantially fulfill current energy demand and reduce environmental pollution in the valley by replacing fossil fuels with clean solar electricity.

Clean energy and clean environment are the ones we desire for our society, our country and our planet earth. Therefore, in order to solve energy shortage and environmental pollution problems, application of clean energy, namely solar energy is urgent and the concerning authorities should think about for necessary clean energy policy.

\section{ACKNOWLEDGEMENT}

We thank Department of Hydrology and Meteorology (DHM), Ministry Environment, Science and Technology, Government of Nepal for providing solar data utilized in this study. The manuscript has been greatly improved from the comments and suggestion of Mr. Saraju K. Baidya, DDG, DHM; we thank him too.

\section{REFERENCES}

Adhikari S., Adhikary S. and Umeno M., 2003. PV Energy Potential in Nepal Himalayas: Analytical Study on Seasonal and Spatial Variation of Solar Irradiation for PV. World Conference on Photovoltaic Energy Conversion (WCPEC-3) 2027-2030.
Adhikari, S., 2007. Ph.D. Thesis - Synthesis and Characterization of carbon thin films and their application to photovoltaic solar cells, $162 \mathrm{pp}$.

Central Bureau of Statistics: Homepage : www.cbs. gov.np

Central Bureau of Statistics, 2011. Preliminary Results of National Population Census.

Department of Hydrology and Meteorology: Homepage : www.dhm.gov.np

Department of Hydrology and Meteorology, 1987. Climatological Records of Nepal (19761984).

Department of Hydrology and Meteorology, 1977. Climatological Records of Nepal (19211975).

Department of Hydrology and Meteorology, 1988. Climatological Records of Nepal (19851986).

Department of Hydrology and Meteorology, 1992. Climatological Records of Nepal (19871990).

Department of Hydrology and Meteorology, 1997. Climatological Records of Nepal (19911994).

Department of Hydrology and Meteorology, 1999. Climatological Records of Nepal (19951996).

Department of Hydrology and Meteorology, 2001. Climatological Records of Nepal (19971998).

Ibrahim, S.M.A., 1985. Predicted and measured global solar radiation in Egypt. Solar Energy 35: 185-188.

Nayava, J.L., 1979. Topoclimatology of the Kathmandu Valley. Proceedings of Tenth Newzealand Geography Conference and Forty-Nine Anzaas Congress, pp 33-38.

Nayava, J.L. 2012. Climates of Nepal and their implications, WWF Nepal. Pages 164.

Nepal Electricity Authority: Homepage : www.nea. org.np 
Nepal Oil Corporation: Homepage : www.nepaloil. com

Neville, R.C., 1995. Solar energy conversion the solar cell, 2nd ed., Elsevier Science B.V., Amsterdam, Netherlands.

Oke, T.R., 1999. Boundary Layer Climates (second edition). University Press, Cambridge. 435pp.

Paudel, K.N., Bhattarai, B.K., Sapkota, B., and Kjeldstad, B., 2011. Solar Radiation Potential at Four Sites of Nepal. Journal of the Institute of Engineering, Vol. 8, No. 3, pp. 189-197.

Pokharel, S., 1998. Energy in Nepal. WECS Library Report no. Tech./030998/1/1 Seq. No. 030), Kathmandu, Nepal.

Regmi, S., 2010. Renewable energy potential and environmental issues in Nepal. M. Sc. Dissertation, Central Department of Hydrology and Meteorology, T.U., Kirtipur, Kathmandu.
Schweizer P., J.N. Shrestha, and D. Sharma., 1995. What can Solar Electricity provide for the Himalayan People? The case of Nepal. 13th European Photovoltaic Solar Energy Conference and Exhibition, Nice: E.C., France. Pages 1791-1795.

Umeno, M., 2003. Research and development of amorphous carbon thin film solar cell supported by NEDO (in Japanese). Antenna No. 54: 1-2.

Water and Energy Commission Secretariat: Homepage : www.wec.gov.np

Water and Energy Commission Secretariat, 2006. Energy Synopsis Report (no. 7, Seq. no. 489), Kathmandu, Nepal. 